\title{
Over fertilization limits lettuce productivity because of osmotic stress
}

\author{
Francisco Albornoz ${ }^{*}$, and J. Heinrich Lieth ${ }^{2}$
}

It is customary that growers apply high doses of nutrients to the soil in order to achieve high yields, with detrimental consequences for the environment; but no information exists with regards to the crop response to high fertilization levels. To evaluate the physiological response of lettuce (Lactuca sativa L.) to various root zone nutrient concentrations (expressed as electrical conductivity, from 0.6 to $10 \mathrm{dS} \mathrm{m}^{-1}$ ), a replicated experiment was conducted using increasing concentrations of macronutrients applied to the root zone in an aeroponic system. Leaf photosynthesis and chlorophyll fluorescence were measured using a portable infrared gas analyzer attached with a fluorometer. Leaf nutrient content was analyzed by mass spectrometry and $\mathrm{NO}_{3}-\mathrm{N}$ was determined by flow injection analysis. Leaf photosynthetic rates increased when the solution concentration was raised from 0.6 to $4.8 \mathrm{dS} \mathrm{m}^{-1}$, but further increases in solution concentration did not result in any differences. The enhancement in photosynthetic rates was related to higher concentrations of $\mathrm{N}, \mathrm{P}, \mathrm{Mg}$, and $\mathrm{S}$ in leaves. Leaf $\mathrm{K}$ content was correlated with stomatal conductance. Maximum growth was achieved with solution concentrations between 1.2 and $4.8 \mathrm{dS} \mathrm{m}^{-1}$ while at $10.0 \mathrm{dS} \mathrm{m}^{-1}$ leaf production was reduced by $30 \%$. It is concluded that at high concentration of nutrients supplied in the root zone, yield reduces because of a combination of decreased stomatal conductance and leaf area.

Key words: Aeroponics, chlorophyll fluorescence, Lactuca sativa, leaf nitrate content, nutrient accumulation, tissue nutrient concentration.

\section{INTRODUCTION}

Several studies have characterized plant responses to limited supply of nutrients (Rubio et al., 2003; Hermans et al., 2006; Bucher, 2007; Svistoonoff et al., 2007; Postma and Lynch, 2011) but there is evidence that in agricultural fields, fertilization practices lead in many cases to the opposite situation, increasing nutrient levels in the soil far beyond those required by plants for growth (Vitousek et al., 2009). It is recognized that excessive fertilization derives in salinization of the soil (Endo et al., 2011), but most of the studies on salinity deal with the addition of a single salt or a mix of various salts to reduce the osmotic potential in the solution. This methodology narrows the results to specific responses to certain ions, commonly $\mathrm{Na}^{+}$or $\mathrm{Cl}^{-}$(Lauchli and Grattan, 2007). The response of plant growth to salinity has been characterized as a combination of the following effects: turgor reduction affecting stomatal conductance and cell expansion, growth limitation due to the rate of photosynthesis; and/ or accumulation of salts or specific ions affecting the production of particular metabolites (Munns and Tester,

${ }^{1}$ Instituto de Investigaciones Agropecuarias, INIA La Platina, Santa Rosa 11610, La Pintana, Santiago, Chile.

*Corresponding author (francisco.albornoz@inia.cl).

${ }^{2}$ University of California, Department of Plant Sciences, One Shields Ave., MS 2, Davis, CA 95616, USA.

Received: 4 December 2014.

Accepted: 24 April 2015.

doi:10.4067/S0718-58392015000400003
2008). Literature reports indicate that salt-sensitive plants exposed to high salinity levels, show a reduction in leaf photosynthesis, due mainly to a disruption in $\mathrm{C}$ metabolic pathways and redox reactions in the thylakoid membranes as well as in the Calvin cycle, because of the accumulation of $\mathrm{Na}^{+}$or $\mathrm{Cl}^{-}$in leaves (Zhang and Xing, 2008). Because of this, commercial growers within USA are advised that salinity levels, measured as electrical conductivity (EC), above $3.0 \mathrm{dS} \mathrm{m} \mathrm{m}^{-1}$ impose a significant hazard (Oki and Lieth, 2004).

Another issue arises in lettuce (Lactuca sativa L.) crops exposed to high levels of $\mathrm{N}$, which is the accumulation of nitrate $\left(\mathrm{NO}_{3}^{-}\right)$in leaves, stored into the vacuoles (Pavlou et al., 2007). This has been associated with health issues in consumers (Katan, 2009), reason why the European Union and the World Health Organization limit the concentration of $\mathrm{NO}_{3}{ }^{-}$in lettuce leaves for fresh consumption to 4500 and $3500 \mathrm{mg} \mathrm{kg}^{-1}$ in a fresh weight (fw) basis for winter and summer crops, respectively (European Union, 2006). However, information on lettuce response to high supply of other nutrients is not available.

The experiment reported in this article studied the response of lettuce plants to balanced increases in nutrients supplied to the root zone. To restrict the response of plants to the concentration of nutrients avoiding interactions with soil factors, plants were grown in an aeroponic system. The objective of this study was to determine the effect of various concentrations of nutrients in the root zone on plant growth and leaf photosynthesis of lettuce plants grown aeroponically. The results are advised for 
consideration when designing the fertilization programs of lettuce.

\section{MATERIALS AND METHODS}

\section{Plant material and growth conditions}

Lettuce (Lactuca sativa L.) 'Black Seeded Simpson' (Lake Valley Seed, Boulder, Colorado, USA) plants were grown in a greenhouse in spring 2012, in Davis, California, USA. Seeds were germinated in seedling trays containing peat, sand, and redwood compost $(1: 1: 1 \mathrm{v} / \mathrm{v})$. Trays were kept on a mist bench until plants had two true leaves, after which plants were moved to a greenhouse with natural day/night light conditions and daily and night average temperature of 28 and $22{ }^{\circ} \mathrm{C}$, respectively.

In the greenhouse, plants were placed in aeroponic systems (model AeroFlow6; General Hydroponics, Sebastopol, California, USA), consisting of rectangular $1.2 \mathrm{~m}$-long white channels (Figure 1). Within these channels, the nutrient solution was sprayed in a fine spray from a reservoir using a pump with a continuous flow rate of $3 \mathrm{~m}^{3} \mathrm{~h}^{-1}$ resulting in a relative humidity of the root zone close to $100 \%$. The water flowed back into the reservoir and it was pumped continuously $24 \mathrm{~h}$ a day. Six plants were placed in each channel using $7.6 \mathrm{~cm}$ coconut baskets filled with the same substrate used to germinate the seeds. Roots grew freely into the channel.

\section{Experimental design}

Six concentrations of a standard nutrient solution (14 $\mathrm{mM} \mathrm{NO}_{3}^{-}, 1 \mathrm{mM} \mathrm{NH}_{4}^{+}, 4 \mathrm{mM} \mathrm{Ca}^{2+}, 2 \mathrm{mM} \mathrm{Mg}^{2+}, 6 \mathrm{mM}$ $\mathrm{K}^{+}, 1 \mathrm{mM} \mathrm{H}_{2} \mathrm{PO}_{4}^{-}$, and $2 \mathrm{mM} \mathrm{SO}_{4}^{2-;} 90 \mu \mathrm{M} \mathrm{B}, 36 \mu \mathrm{M}$ $\mathrm{Cl}, 18 \mu \mathrm{M} \mathrm{Mn}, 1.4 \mu \mathrm{M} \mathrm{Zn}, 0.62 \mu \mathrm{M} \mathrm{Cu}, 90 \mu \mathrm{M} \mathrm{Fe}$, and $0.20 \mu \mathrm{M}$ Mo; Albornoz and Lieth, 2015) (Table 1) were tested to determine the effect on plant growth and leaf photosynthesis. Proportional quantities of all the nutrients were calculated to achieve the desired concentrations. The $\mathrm{pH}$ of the solution was adjusted to 5.8 using $\mathrm{KOH}$ or $\mathrm{H}_{2} \mathrm{SO}_{4}$ when required. The corresponding nutrient solution for each treatment was mixed directly in the reservoir of each treatment. Three replicates of each nutrient concentration level (channel) were used in a completely randomized design. This experiment was replicated three times. The

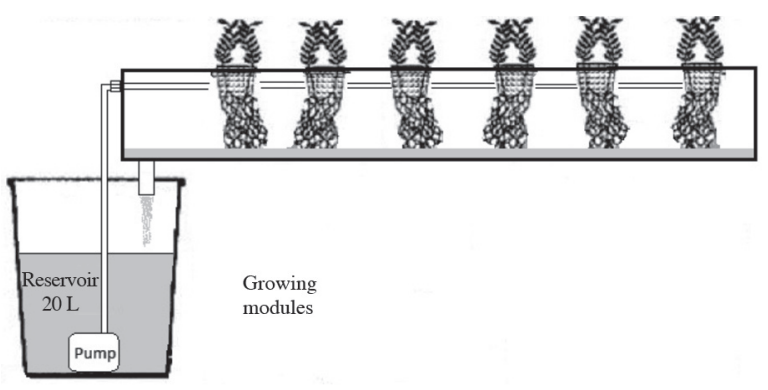

Figure 1. Aeroponic system used to grow lettuce plants for the study.
Table 1. Concentration of macronutrients in the nutrient solution treatments used in the experiments.

\begin{tabular}{|c|c|c|c|c|c|c|c|}
\hline $\begin{array}{l}\text { Treatment/ } \\
\text { EC level }\end{array}$ & $\mathrm{NO}_{3}^{-}$ & $\mathrm{NH}_{4}^{+}$ & $\mathrm{H}_{2} \mathrm{PO}_{4}^{-}$ & $\mathrm{K}^{+}$ & $\mathrm{Ca}^{2+}$ & $\mathrm{Mg}^{2+}$ & $\mathrm{SO}_{4}$ \\
\hline $\mathrm{dS} \mathrm{m}^{-1}$ & 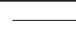 & 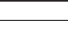 & 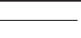 & $\mathrm{mmol} \mathrm{L}$ & & & 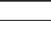 \\
\hline EC-0.6 & 3.5 & 0.25 & 0.25 & 1.5 & 1.0 & 0.5 & 0.5 \\
\hline EC-1.2 & 7.0 & 0.50 & 0.50 & 3.0 & 2.0 & 1.0 & 1.0 \\
\hline EC-2.4 & 14.0 & 1.00 & 1.00 & 6.0 & 4.0 & 2.0 & 2.0 \\
\hline EC-4.8 & 28.0 & 2.00 & 2.00 & 12.0 & 8.0 & 4.0 & 4.0 \\
\hline EC-6.0 & 35.0 & 2.50 & 2.50 & 15.0 & 10.0 & 5.0 & 5.0 \\
\hline EC-10.0 & 70.0 & 5.00 & 5.00 & 30.0 & 20.0 & 10.0 & 10.0 \\
\hline
\end{tabular}

EC: Electrical conductivity of the nutrient solution.

solution was discarded twice per week and replaced with fresh solution to avoid substantial changes in the EC.

After 3 wk (24 d after transplant) of growth in the greenhouse, single leaf photosynthetic rates $\left(A_{n}\right)$, stomatal conductance $\left(\mathrm{g}_{\mathrm{s}}\right)$, and transpiration were measured in the youngest fully expanded leaf of 10 plants from each nutrient concentration treatment. Measures were carried out using a portable infrared gas analyzer (model LI-6400XT; LI-COR Bioscience, Lincoln, Nebraska, USA). Ten light response curves were built for each solution concentration treatment. The light levels, expressed as photosynthetic photon flux (PPF), used in each curve were $2000,1600,1200,800,400$, and 0 $\mu \mathrm{mol} \mathrm{PPF} \mathrm{m}^{-2} \mathrm{~s}^{-1}$. To achieve each light level, the cuvette of the infrared gas analyzer featured an LED light source (model 6400-02B; LI-COR Bioscience). The conditions within the cuvette were controlled so as to maintain leaf temperature at $25^{\circ} \mathrm{C}$, ambient $\mathrm{CO}_{2}$ concentration at 380 $\mu \mathrm{mol} \mathrm{mol}^{-1}$ and constant water mole fraction of $20 \mathrm{mmol}$ $\mathrm{mol}^{-1}$. A minimum of 15 min was allowed between light levels for the measurement to be stable before logging data. The measurement was defined as stable when the rate of change in photosynthesis was lower than $0.1 \mu \mathrm{mol}$ $\mathrm{CO}_{2} \min ^{-1}$.

Each single curve obtained with the gas exchange system was fitted to a non-rectangular hyperbola using the non-linear procedure (PROC NLIN) in SAS software (SAS Institute, Cary, North Carolina, USA), in order to determine maximum photosynthetic rate $\left(\mathrm{P}_{\mathrm{m}}\right)$ and dark respiration $\left(\mathrm{R}_{\mathrm{d}}\right)$, as in Equation [1]:

$\mathrm{A}_{\mathrm{n}}=\left(\left(\alpha \cdot \mathrm{I}+\mathrm{P}_{\mathrm{m}}-\left(\left(\alpha \cdot \mathrm{I}+\mathrm{P}_{\mathrm{m}}\right)^{2}-4 \alpha \cdot \mathrm{I} \cdot \mathrm{P}_{\mathrm{m}} \cdot \theta\right)^{1 / 2}\right) / 2 \theta\right)-\mathrm{R}_{\mathrm{d}}[1]$ where $\mathrm{A}_{\mathrm{n}}$ is net $\mathrm{CO}_{2}$ assimilation rate $\left(\mu \mathrm{mol} \mathrm{m}^{-2} \mathrm{~s}^{-1}\right), \alpha$ is the apparent quantum yield, I is the incident photosynthetic photon flux, $\mathrm{P}_{\mathrm{m}}$ the maximum rate of photosynthesis $\left(\mu \mathrm{mol} \mathrm{m} \mathrm{m}^{-2} \mathrm{~s}^{-1}\right), \mathrm{R}_{\mathrm{d}}$ dark respiration rate $\left(\mu \mathrm{mol} \mathrm{m} \mathrm{m}^{-2} \mathrm{~s}^{-1}\right)$, and $\theta$ is a dimensionless constant (Marshall and Biscoe, 1980).

Along with the gas exchange measurements, chlorophyll fluorescence measurements were conducted using a leaf chamber fluorometer (model LI-6400-40; LICOR Bioscience). The measuring beam in the fluorometer was set at an intensity of 5, with a modulation of $20 \mathrm{kHz}$ and a gain factor of 10 . The saturating flash was set at an intensity of 8 with duration of $0.8 \mathrm{~s}$ with a modulation of $20 \mathrm{kHz}$ and an average filter of $50 \mathrm{~Hz}$. Chlorophyll 
fluorescence measurements were used for the calculation of the fraction of absorbed photons used in photochemistry $\left(\Phi_{\text {PSII }}\right)$ as in Equation [2]:

$$
\Phi_{\text {PSII }}=\left(\mathrm{F}_{\mathrm{m}}{ }^{\prime}-\mathrm{F}_{\mathrm{s}}\right) / \mathrm{F}_{\mathrm{m}},
$$

where $\mathrm{F}_{\mathrm{m}}$ ' corresponds to the maximal fluorescence during a saturating light flash and $\mathrm{F}_{\mathrm{s}}$ is the steady state fluorescence (Baker, 2008). The quantum yield of $\mathrm{CO}_{2}$ assimilation ( $\mathrm{mol} \mathrm{CO} \mathrm{mol}^{-1}$ photon, $\Phi_{\mathrm{CO}_{2}}$ ) at 400,800 , 1200,1600 , and $2000 \mu \mathrm{mol} \mathrm{m} \mathrm{m}^{-2} \mathrm{~s}^{-1}$ was calculated as in Equation [3]

$$
\Phi_{\mathrm{CO}_{2}}=\left(\mathrm{A}_{\mathrm{n}}-\mathrm{A}_{\mathrm{d}}\right) / \mathrm{I} \cdot \alpha_{\text {leaf }}
$$

where $A_{n}$ is the assimilation rate $\left(\mu \mathrm{mol} \mathrm{CO} \mathrm{m}^{-2} \mathrm{~s}^{-1}\right), \mathrm{A}_{\mathrm{d}}$ is the dark assimilation rate $\left(\mu \mathrm{mol} \mathrm{CO}_{2} \mathrm{~m}^{-2} \mathrm{~s}^{-1}\right), \mathrm{I}$ is the incident photon flux density $\left(\mu \mathrm{mol} \mathrm{m} \mathrm{m}^{-2} \mathrm{~s}^{-1}\right)$, and $\alpha_{\text {leaf }}$ is leaf absorptance. In lettuce, the leaf absorptance value using red and blue LED's has been reported to be 0.89 (Kim et al., 2004).

\section{Leaf nutrient concentration}

After 4 wk of cultivation in greenhouse, plants were harvested and fresh weight of shoot and roots was recorded. Total leaf area was measured using a leaf area meter (model LI-3100C, LI-COR Bioscience). Plants were placed individually in paper bags and dried in an oven at $60{ }^{\circ} \mathrm{C}$ for $72 \mathrm{~h}$. Dry weight of leaves was recorded. The plant material was ground to pass through a 40 mesh sieve. Total $\mathrm{N}$ concentration was determined by sample combustion coupled with thermal conductivity/ IR detection. Extractable $\mathrm{NO}_{3}{ }^{-}$was analyzed by flow injection analysis after extraction with $2 \%$ acetic acid. The concentration of $\mathrm{P}, \mathrm{K}, \mathrm{Ca}, \mathrm{Mg}$, and $\mathrm{S}$ was determined by nitric acid digestion/hydrogen peroxide microwave digestion and determination by inductively coupled plasma-atomic emission spectrometry (ICP-AES). Total non-structural carbohydrates (TNC), as well as the concentration of glucose, sucrose and fructose, were analyzed by HPLC with mass selection detection.

\section{Statistical analysis}

Data from each replicate of the experiment were pooled together into one data set to be analyzed using the SAS software package (SAS Institute, Cary, North Carolina, USA). Differences in $P_{m}$ and $R_{d}$ were analyzed across the solution concentration levels using a generalized linear model (GLM) approach. Leaf $\mathrm{CO}_{2}$ assimilation rate, stomatal conductance, transpiration rate, quantum yield, and photochemistry efficiencies were analyzed by GLM at every light level. Differences in plant biomass, leaf area, leaf nutrient and sugar content among treatments were analyzed by ANOVA. Tukey's honestly significant difference test was used for pairwise comparison.

\section{RESULTS}

\section{Plant growth}

The highest shoot fresh and dry weight were achieved in plants exposed to the solution with $1.2 \mathrm{dS} \mathrm{m}^{-1}$ and no significant differences were found when compared to concentrations equivalent to 2.4 or $4.8 \mathrm{dS} \mathrm{m}^{-1}$ (Table 2 ). The most diluted solution yielded the lowest fresh and dry weight of plant shoot. The lowest root biomass was found in those treatments with the highest concentrations (6.0 and $\left.10.0 \mathrm{dS} \mathrm{m}^{-1}\right)$, while the highest values for fresh and dry root weight were found at a concentration of $1.2 \mathrm{dS} \mathrm{m}^{-1}$. Leaf area increased when the concentration of nutrients was raised from 0.6 to $1.2 \mathrm{dS} \mathrm{m}^{-1}$ to gradually decline with later increases in the solution concentration.

\section{Gas exchange measurements}

Increasing concentration of nutrients gradually increased the photosynthetic rates, when the concentration of the nutrient solution ranged from 0.6 to $4.8 \mathrm{dS} \mathrm{m}^{-1}$ (Figure 2). Further increases in the concentration of nutrients in the solution made no differences in the photosynthetic rates. Dark respiration did not saturate, increasing with each nutrient concentration increase.

Stomatal conductance and transpiration showed a curvilinear pattern in response to the applied treatments, increasing gradually with solution concentration increases, reaching their maximum levels between 1.2 and $4.8 \mathrm{dS}$ $\mathrm{m}^{-1}$, to later decline with further solution concentration increases (Figure 3). This response is independent of the light level at which gas exchange was measured.

The analysis of chlorophyll fluorescence showed that the quantum yield decreased from 0.60 to 0.15 with increasing PPF levels between 400 and $2000 \mu \mathrm{mol}$ $\mathrm{m}^{-2} \mathrm{~s}^{-1}$. No differences were found between the nutrient concentration treatments. However, the quantum efficiency in $\mathrm{CO}_{2}$ assimilation increased with increasing

Table 2. Fresh and dry weight of shoot and root and total leaf area of lettuce plants at various root zone nutrient concentration levels, expressed

\begin{tabular}{|c|c|c|c|c|c|c|}
\hline \multirow[b]{2}{*}{ Treatment } & \multicolumn{3}{|c|}{ Fresh weight } & \multicolumn{2}{|c|}{ Dry weight } & \multirow[b]{2}{*}{ Leaf area } \\
\hline & Shoot & Root & Root/Shoot & Shoot & Root & \\
\hline & & g plant $^{-1}$ & - & $\longrightarrow$ & g plant $^{-1}$ & $\mathrm{~cm}^{2}$ \\
\hline EC-0.6 & $97.1 \pm 10.8 \mathrm{c}$ & $8.9 \pm 0.9 b$ & $0.091 \pm 0.001 \mathrm{a}$ & $3.79 \pm 0.42 b$ & $0.36 \pm 0.04 b$ & $1711.7 \pm 143.3 \mathrm{c}$ \\
\hline $\mathrm{EC}-1.2$ & $175.1 \pm 19.1 \mathrm{a}$ & $16.2 \pm 2.3 \mathrm{a}$ & $0.092 \pm 0.002 \mathrm{a}$ & $6.77 \pm 0.85 a$ & $0.65 \pm 0.09 \mathrm{a}$ & $3245.4 \pm 298.6 a$ \\
\hline EC-2.4 & $163.8 \pm 9.4 \mathrm{ab}$ & $8.1 \pm 0.5 b$ & $0.049 \pm 0.001 b$ & $6.88 \pm 0.40 \mathrm{a}$ & $0.34 \pm 0.02 b$ & $2675.6 \pm 155.4 \mathrm{ab}$ \\
\hline $\mathrm{EC}-4.8$ & $160.7 \pm 9.1 \mathrm{ab}$ & $7.4 \pm 0.5 b c$ & $0.046 \pm 0.001 \mathrm{~b}$ & $7.39 \pm 0.51 \mathrm{a}$ & $0.27 \pm 0.02 b c$ & $2632.1 \pm 173.2 \mathrm{ab}$ \\
\hline EC-6.0 & $113.2 \pm 8.4 \mathrm{bc}$ & $2.6 \pm 1.3 c$ & $0.022 \pm 0.001 \mathrm{c}$ & $5.69 \pm 0.66 \mathrm{ab}$ & $0.12 \pm 0.06 c$ & $2469.9 \pm 143.9 \mathrm{ab}$ \\
\hline EC-10.0 & $124.9 \pm 7.3 \mathrm{bc}$ & $2.4 \pm 0.1 \mathrm{c}$ & $0.019 \pm 0.001 \mathrm{c}$ & $6.24 \pm 0.36 a$ & $0.12 \pm 0.01 \mathrm{c}$ & $2073.9 \pm 108.6 \mathrm{bc}$ \\
\hline
\end{tabular}
as electrical conductivity (EC).

Values are means \pm Standard error. Different letters in the same column denote differences according Tukey test $(\mathrm{P}<0.05)$. 

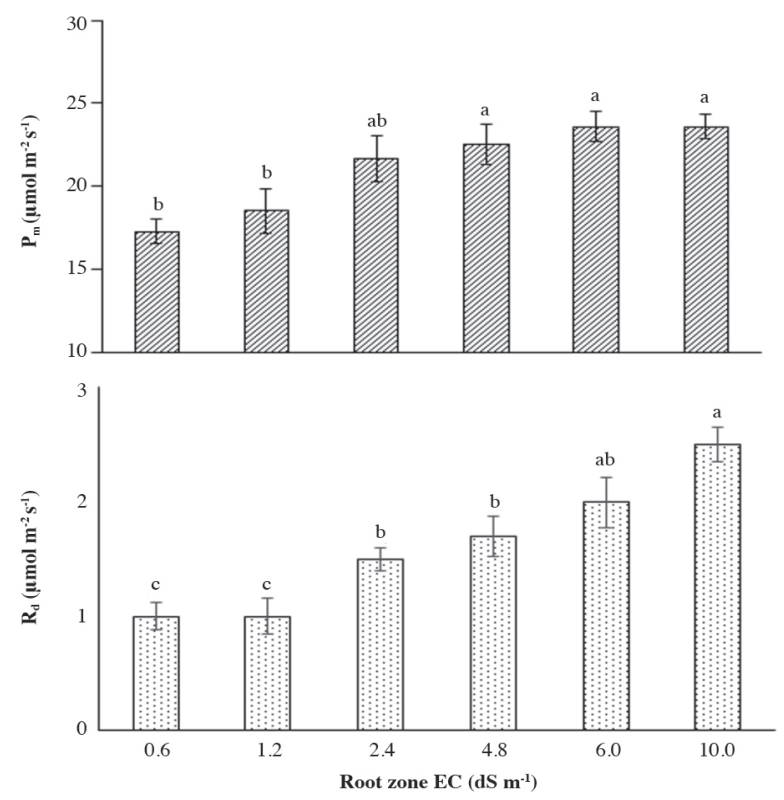

Different letters denote differences according Tukey test $(\mathrm{P}<0.05)$.

Figure 2. Maximum photosynthetic rate $\left(\mathrm{P}_{\mathrm{m}}\right)$ and dark respiration $\left(\mathbf{R}_{\mathrm{d}}\right)$ from each nutrient concentration treatment, expressed as electrical conductivity (EC).
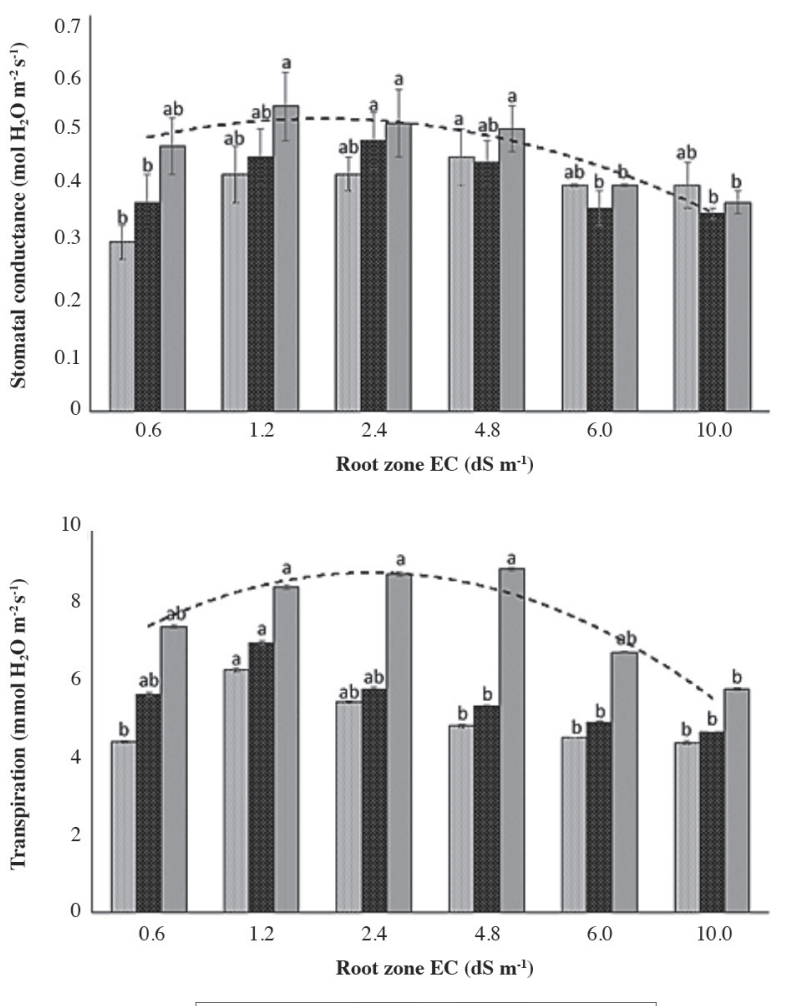

Different letters across the same photosynthetic photon flux (PPF) level, denote differences according Tukey test between solution concentrations treatments $(\mathrm{P}<0.05)$.

Figure 3. Stomatal conductance and transpiration rate measured at $25{ }^{\circ} \mathrm{C}$ in lettuce leaves with roots exposed to different nutrient solution concentrations, expressed as electrical conductivity (EC). concentration of nutrients supplied, showing the lowest values in those plants treated with the most diluted solution.

\section{Leaf nutrient concentration}

Increasing concentration of nutrients in the root zone led to increased concentration of $\mathrm{N}, \mathrm{P}, \mathrm{S}$, and $\mathrm{Mg}$ in leaf tissue (Table 3). Total $\mathrm{N}$ concentration in leaves increased from 51.9 $\pm 0.4 \mathrm{~g} \mathrm{~kg} \mathrm{k}^{-1} \mathrm{dw}$ at the lowest solution concentration to $69.4 \pm$ $1.3 \mathrm{~g} \mathrm{~kg}^{-1} \mathrm{dw}$ with a concentration of $6.0 \mathrm{dS} \mathrm{m}^{-1}$ showing no difference with plants exposed to $10.0 \mathrm{dS} \mathrm{m}^{-1}$. Similar results were found for $P$, with the lowest value $\left(8.9 \pm 0.1 \mathrm{~g} \mathrm{~kg}^{-1} \mathrm{dw}\right)$ at $0.6 \mathrm{dS} \mathrm{m}^{-1}$ and a maximum of $15.8 \pm 0.3 \mathrm{~g} \mathrm{~kg}^{-1} \mathrm{dw}$ with the 6.0 $\mathrm{dS} \mathrm{m}{ }^{-1}$ concentration. The lowest values of $\mathrm{S}$ were found in those treatments with 0.6 and $1.2 \mathrm{dS} \mathrm{m}^{-1}$, with an average of $3.7 \pm 0.1\left(\mathrm{~g} \mathrm{~kg}^{-1} \mathrm{dw}\right)$. Sulfur content increased up to a value of $7.2 \pm 0.1 \mathrm{~g} \mathrm{~kg}^{-1} \mathrm{dw}$ in plants exposed to $6.0 \mathrm{dS} \mathrm{m}^{-1}$ to decrease with higher concentration levels to a value of $5.5 \pm 0.01 \mathrm{~g} \mathrm{~kg}^{-1} \mathrm{dw}$. Magnesium concentration increased from the lowest concentration treatment to the 4.8 $\mathrm{dS} \mathrm{m} \mathrm{m}^{-1}$ treatment been not different in plants exposed to higher concentration levels. Calcium concentration was not affected by the treatments, with an average value of $17.3 \pm 0.6\left(\mathrm{~g} \mathrm{~kg}^{-1} \mathrm{dw}\right)$.

Potassium concentration increased when plants were exposed to 1.2 and $2.4 \mathrm{dS} \mathrm{m}^{-1}\left(94.6 \pm 5.3 \mathrm{~g} \mathrm{~kg}^{-1} \mathrm{dw}\right)$ but higher concentration of nutrients in the solution reduced $\mathrm{K}$ concentration to the same level as in plants treated with the most diluted solution $\left(78.2 \pm 2.7 \mathrm{~g} \mathrm{~kg}^{-1} \mathrm{dw}\right)$. Leaf $\mathrm{K}$ concentration showed a significant correlation with stomatal conductance $(\mathrm{p}<0.0036)$.

The concentration of nitrate was significantly lower ( $4.95 \pm 0.09 \mathrm{~g} \mathrm{~kg}^{-1} \mathrm{dw}$, equivalent to $247.7 \pm 4.72 \mathrm{mg} \mathrm{kg}^{-1}$ $\mathrm{fw}$ ) in leaves of plants treated with $0.6 \mathrm{dS} \mathrm{m}^{-1}$ solution, in comparison to $13.59 \pm 0.09 \mathrm{~g} \mathrm{~kg}^{-1} \mathrm{dw}$ (equivalent to $679.5 \pm 47.6 \mathrm{fw})$ in the other treatments. No differences were found between plants between 1.2 and $10.0 \mathrm{dS} \mathrm{m}^{-1}$ (Table 3).

No differences were found in the concentration of non-structural carbohydrates between the nutrient concentration treatments. The average content of nonstructural carbohydrates was $64.3 \pm 4.8 \mathrm{~g} \mathrm{~kg}^{-1} \mathrm{dw}$; where sucrose was found in higher amount $\left(41.1 \pm 3.0 \mathrm{~g} \mathrm{~kg}^{-1} \mathrm{dw}\right)$ followed by glucose $\left(14.4 \pm 1.7 \mathrm{~g} \mathrm{~kg}^{-1} \mathrm{dw}\right)$ and fructose $\left(9.0 \pm 0.6 \mathrm{~g} \mathrm{~kg}^{-1} \mathrm{dw}\right)$.

\section{DISCUSSION}

\section{Physiological limitations at high nutrient supply}

The results show no evidence of plant toxicity because of the increased concentrations of nutrients, showing similar efficiencies of the PSII system across the applied treatments, which reflects no limitation at the biochemical level, i.e. the electron transport capacity in PSII. However, the quantum yield (the amount of $\mathrm{CO}_{2}$ absorbed per photon absorbed) was higher in those plants 
Table 3. Concentration of nutrients in leaf tissue of plants supplied with different concentrations of nutrients, expressed as electrical conductivity (EC).

\begin{tabular}{|c|c|c|c|c|c|c|}
\hline \multirow{2}{*}{$\begin{array}{l}\text { Nutrient } \\
\left(\mathrm{g} \mathrm{kg}^{-1} \mathrm{dw}\right)\end{array}$} & \multicolumn{6}{|c|}{ Treatment } \\
\hline & EC-0.6 & EC-1.2 & EC-2.4 & EC-4.8 & EC-6.0 & EC-10.0 \\
\hline $\bar{N}$ & $51.9 \pm 0.5 \mathrm{~d}$ & $57.7 \pm 1.3 \mathrm{c}$ & $59.4 \pm 0.3 c$ & $63.9 \pm 1.1 b$ & $69.4 \pm 1.3 \mathrm{ab}$ & $71.1 \pm 0.2 \mathrm{a}$ \\
\hline $\mathrm{P}$ & $9.0 \pm 0.1 \mathrm{~d}$ & $9.0 \pm 1.0 \mathrm{~d}$ & $10.6 \pm 0.2 \mathrm{c}$ & $13.7 \pm 0.4 b$ & $15.8 \pm 0.4 \mathrm{a}$ & $14.4 \pm 0.3 \mathrm{ab}$ \\
\hline $\mathrm{K}$ & $79.7 \pm 0.7 b$ & $92.8 \pm 6.0 \mathrm{a}$ & $96.5 \pm 4.7 \mathrm{a}$ & $85.2 \pm 3.0 b$ & $71.9 \pm 4.3 b$ & $76.1 \pm 0.8 b$ \\
\hline $\mathrm{Ca}$ & $16.7 \pm 0.5 \mathrm{ab}$ & $20.2 \pm 0.3 a$ & $13.9 \pm 1.3 b$ & $16.4 \pm 1.5 b$ & $18.1 \pm 0.6 \mathrm{ab}$ & $18.6 \pm 0.1 \mathrm{ab}$ \\
\hline $\mathrm{Mg}$ & $4.1 \pm 0.01 b$ & $4.7 \pm 0.1 b$ & $4.1 \pm 0.1 b$ & $5.5 \pm 0.4 \mathrm{a}$ & $5.7 \pm 0.2 \mathrm{a}$ & $5.9 \pm 0.01 a$ \\
\hline $\mathrm{S}$ & $3.6 \pm 0.1 \mathrm{c}$ & $3.9 \pm 0.01 \mathrm{c}$ & $4.4 \pm 0.01 \mathrm{c}$ & $5.9 \pm 0.2 b$ & $7.3 \pm 0.1 \mathrm{a}$ & $5.6 \pm 0.01 b$ \\
\hline $\mathrm{NO}_{3}-\mathrm{N}$ & $4.95 \pm 0.09 b$ & $12.51 \pm 2.31 \mathrm{a}$ & $11.81 \pm 0.48 \mathrm{a}$ & $14.36 \pm 0.43 \mathrm{a}$ & $14.11 \pm 1.32 \mathrm{a}$ & $15.15 \pm 0.22 \mathrm{a}$ \\
\hline
\end{tabular}

Values are means \pm standard error. Different letters in the row denote differences according Tukey test $(\mathrm{P}<0.05)$.

treated with the most concentrated nutrient solutions. The photosynthetic capacity is highly related to the nutrient content of the leaves, especially $\mathrm{N}$ which is the primary constituent of the proteins involved in the Calvin cycle and in the thylakoid membranes, along with $\mathrm{P}, \mathrm{Mg}$, and $\mathrm{S}$ (Amtmann and Armengaud, 2009; Maathuis, 2009). It is not surprising then that in our experiment increases in the availability of nutrients to the plants resulted in higher values of $\mathrm{P}_{\mathrm{m}}$, since leaf $\mathrm{N}, \mathrm{P}, \mathrm{Mg}$, and $\mathrm{S}$ content also increased. This is in accordance to the results provided by other authors (Jiang et al., 2004), who reported how balanced N-P-K increases in the fertilization supplied to wheat and maize crops enhanced leaf photosynthesis. A decrease in the N/P ratio is observed with increasing concentrations of nutrients, which is in agreement with the data provided by Rivas-Ubach et al. (2012), who reported a reduction in the $\mathrm{N} / \mathrm{P}$ ratio of leaves when the metabolic activity is increased, a situation observed in our experiments by the increase in the photosynthetic activity.

The limitation for plant growth at high fertilization doses came from a reduction in stomatal conductance and leaf transpiration which derived in lower water content in leaves, reducing, therefore, leaf expansion and total leaf area. This is a direct response to the low osmotic potential of the solution sprayed to the roots (Eraslan et al., 2007). The lowest values for stomatal conductance were found in those treatments with the lowest and the highest concentrations, which were intimately related to the leaf $\mathrm{K}$ content, since it has a major effect on stomatal conductance (Jin et al., 2011).

Plants under salinity stress show an accumulation of sugars in leaves (Munns and Tester, 2008), but in our experiment no differences were found in the sugar concentration. With increasing salinity, the respiration rate measured as dark respiration $\left(R_{d}\right)$ also increased, explaining why no differences in sugar concentration among treatments were found.

\section{Plant growth}

The lowest leaf biomass was obtained with the lowest concentration of the nutrient solution but it increased rapidly when doubling the concentration of nutrients from 0.6 to $1.2 \mathrm{dS} \mathrm{m}^{-1}$. Silber et al. (2003) working with lettuce found that plants grown with diluted nutrient solutions reduced their production due to $\mathrm{N}$ and $\mathrm{P}$ deficiencies. Our results support their findings since the treatment with the

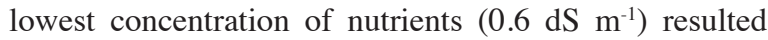
in the lowest photosynthetic rates and at the same time showed the lowest nutrient contents in leaves, presenting a pale green coloration. On the other hand, high nutrient supply does not further increase productivity, as shown by Johnstone et al. (2005) who analyzed the response of lettuce to heavy $\mathrm{P}$ fertilization.

Plant growth rate is the result of leaf area ratio (LAR) and net $\mathrm{CO}_{2}$ assimilation rate (NAR), as in the following relation: $\mathrm{RGR}=\mathrm{LAR} \times \mathrm{NAR}$ (Lambers et al., 2008). With concentrations higher than $4.8 \mathrm{dS} \mathrm{m}^{-1}$ the photosynthetic rate was maintained but leaf area was significantly reduced (Figure 4).

Lettuce is a moderately salinity sensitive crop, with an electrical conductivity (EC) threshold value for maximum yield at $1.1 \mathrm{dS} \mathrm{m}^{-1}$ and total yield loss when cultivated in soil with irrigation water with EC of $6.0 \mathrm{dS}$ $\mathrm{m}^{-1}$ (Unlukara et al., 2008). Andriolo et al. (2005) working with lettuce cultivated in nutrient film technique (NFT) systems imposed various salinity levels by increasing the concentration of the entire nutrient solution as in our experiment, concluding the threshold value for leaf production was at solution concentration of $0.9 \mathrm{dS} \mathrm{m}^{-1}$ and estimated total yield loss at $11.0 \mathrm{dS} \mathrm{m} \mathrm{m}^{-1}$. The main difference among the cultivation systems mentioned above is the oxygen available in the root zone. The levels

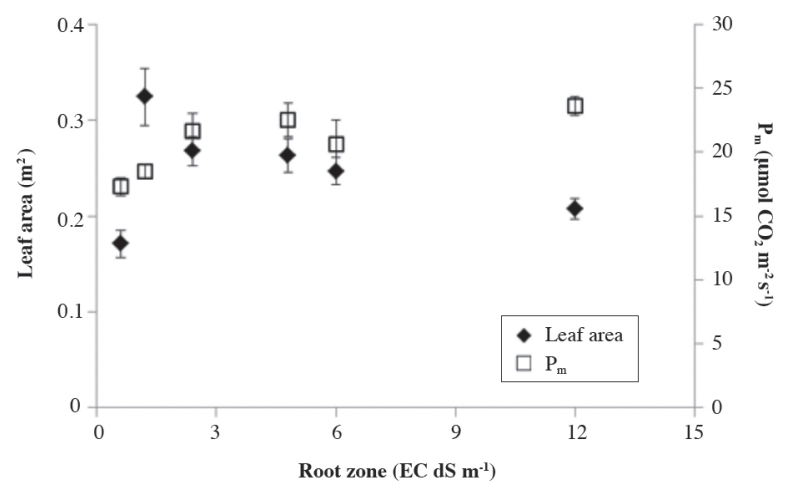

Symbols are means \pm standard error.

Figure 4. Leaf area and maximum leaf photosynthesis $\left(P_{m}\right)$ of lettuce plants at various root zone salinity levels, expressed as electrical conductivity (EC). 
of $\mathrm{O}_{2}$ available for root respiration are in direct relation to plant growth, since water uptake and nutrient absorption are processes highly dependent on root respiration (BarYosef and Lieth, 2013). Under hypoxic conditions, the reduction in water uptake has been related to a decrease in the hydraulic conductivity of the root system while the reduced uptake of nutrients responds to lower activity of the $\mathrm{H}^{+}$-translocating ATPase of the root plasma membrane (Colmer and Voesenek, 2009). In the present study, plants irrigated with a solution of $10.0 \mathrm{dS} \mathrm{m}^{-1}$ showed only a $30 \%$ leaf biomass reduction in comparison to those plants irrigated with the $1.2 \mathrm{dS} \mathrm{m}^{-1}$ solution, with the difference that in common salinity experiments, salts, such as sodium chloride, are added to increase EC, resulting in toxicity effects because of interference of sodium and chloride with plant metabolism (Kalaji et al., 2011).

Root growth was highly affected by the nutrient concentration treatments with a reduction in fresh weight of $\sim 85 \%$ in the most concentrated treatment $\left(10.0 \mathrm{dS} \mathrm{m}^{-1}\right)$ in comparison to the highest root fresh weight achieved with a concentration of $1.2 \mathrm{dS} \mathrm{m}^{-1}$. This is in agreement with the analysis carried out by Poorter et al. (2012), who concluded that plants reduce the partitioning of resources to the roots when grown under high nutrient availability. Plants grown with the lowest solution concentration showed a similar root:shoot ratio than those grown at $1.2 \mathrm{dS} \mathrm{m}^{-1}$ and this ratio decreased with increasing nutrient availability (Table 3 ). The osmotic potential of the solutions in our treatments may have contributed to the reduction of root growth, since low osmotic potential reduces the length of the elongation zone in the root apical meristem (Munns and Tester, 2008).

\section{Leaf nitrate content}

The $\mathrm{NO}_{3}-\mathrm{N}$ content of lettuce leaves has been previously associated to the photosynthetic rates of lettuce plants. It has been hypothesized that lettuce cultivars with low photosynthetic rates use $\mathrm{NO}_{3}-\mathrm{N}$ as a replacement for carbohydrates in the osmotic function they have in growing tissue (Burns et al., 2011). In our experiment, the lowest $\mathrm{NO}_{3}-\mathrm{N}$ content was found in plants exposed to the lowest concentration of nutrients, which in turn, exhibited the lowest photosynthetic rates. Carbohydrates are required for the assimilation of $\mathrm{NO}_{3}{ }^{-}$in the glutamine synthetase/ glutamate synthase (GS/GOGAT) cycle (Lambers et al., 2008), thus, low photosynthetic rates can contribute to the accumulation of $\mathrm{NO}_{3}^{-}$in leaves (Burns et al., 2011). Increases in the availability of nutrients increased the photosynthetic rates and this was accompanied by a marginal increase in $\mathrm{NO}_{3}-\mathrm{N}$ content of leaves of plants exposed to $0.5 \mathrm{X}$ thru 5.0X.

High content of $\mathrm{NO}_{3}^{-}$in leafy vegetables has been associated with health problems in human consumers (Anjana et al., 2007). In these experiments, it was found that $\mathrm{N}$ concentration in leaves increased with increasing nutrient solution concentration, but the values for non-metabolized
$\mathrm{NO}_{3}-\mathrm{N}$ in leaves were more than $75 \%$ below those imposed by the European regulation for plants cultivated under greenhouse conditions (4500 mg kg-1 fw) (Santamaria, 2006), which implies the use of aeroponic systems does not tend to accumulate this ion in the leaves resulting in a product of good quality for human consumption.

\section{CONCLUSIONS}

Excessive additions of fertilizers to lettuce crops reduce productivity because of a limitation on the $\mathrm{K}$ uptake, which is related to a reduction in stomatal conductance. Lettuce plants are not able to compensate for leaf $\mathrm{K}$ reduction, therefore, the ability to maintain stomatal conductance decrease with the consequent reduction in tissue water content. Balanced increases in fertilizer additions increase the uptake of $\mathrm{N}, \mathrm{P}, \mathrm{Mg}$, and $\mathrm{S}$, resulting in a more efficient photosynthetic apparatus.

High quantities of nutrients supplied in aeroponics did not result in toxic accumulation of ions in leaves of lettuce and there is no evidence for damage in the electron transport chain of the Photosystem II. The use of aeroponic culture increased the tolerance of lettuce plants to salinity and limited the accumulation of $\mathrm{NO}_{3}-\mathrm{N}$ in leaves.

\section{ACKNOWLEDGEMENT}

The authors are grateful for the donation of materials from General Hydroponics Inc. This research was funded by the Jastro-Shields funds of the Department of Plant Sciences, University of California, Davis; and by the Fulbright-CONICYT Chile scholarship.

\section{LITERATURE CITED}

Albornoz, F., and J.H. Lieth. 2015. Diurnal macronutrients uptake patterns by lettuce roots under various light and temperature levels. Journal of Plant Nutrition doi:10.1080/01904167.2015.1009098.

Amtmann, A., and P. Armengaud. 2009. Effects of N, P, K and S on metabolism: New knowledge gained from multi-level analysis. Current Opinion in Plant Biology 12:275-283.

Andriolo, J.L., G.L. Luz, M.H. Witter, R.S. Godoi, G.T. Barros, and O.C. Bortolotio. 2005. Growth and yield of lettuce plants under salinity. Horticultura Brasileira 23:931-934.

Anjana, S.U., M. Iqbal, and Y.P. Abrol. 2007. Are nitrate concentrations in leafy vegetables within safe limits? Current Science 92:355-360.

Baker, N.R. 2008. Chlorophyll fluorescence: a probe of photosynthesis in vivo. Annual Review of Plant Biology 59:89-113.

Bar-Yosef, B., and J.H. Lieth. 2013. Effects of oxygen concentration in solution and uptake rate by roots on cut roses yield, and nutrients and sugars content in leaves. Scientia Horticulturae 155:49-55.

Bucher, M. 2007. Functional biology of plant phosphate uptake at root and mycorrhiza interfaces. New Phytologist 173:11-26.

Burns, I.G., K. Zhang, M.K. Turner, and R. Edmondson. 2011. Isoosmotic regulation of nitrate accumulation in lettuce. Journal of Plant Nutrition 34:283-313.

Colmer, T.D., and L.A.Voesenek. 2009. Flooding tolerance: suites of plant traits in variable environments. Functional Plant Biology 36:665-681. 
Endo, T., S. Yamamoto, J.A. Larrinaga, H. Fujiyama, and T. Honna. 2011. Status and causes of soil salinization of irrigated agricultural lands in southern Baja California, Mexico. Applied Environmental Soil Science doi:10.1155/2011/873625.

Eraslan, F., A. Inal, O. Savasturk, and A. Gunes. 2007. Changes in antioxidative system and membrane damage of lettuce in response to salinity and boron toxicity. Scientia Horticulturae 114:5-10.

European Union. 2006. Commission regulation (EC) nr 1881/2006. 19 December 2006 setting maximum levels for certain contaminants in foodstuffs. Official Journal of the European Union 49:5-24.

Hermans, C., J.P. Hammond, P.J. White, and N. Verbruggen. 2006 How do plants respond to nutrient shortage by biomass allocation? Trends in Plant Science 11:610-617.

Jiang, D., T. Dai, Q. Jing, W. Cao, Q. Zhou, H. Zhao, et al. 2004. Effects of long-term fertilization on leaf photosynthetic characteristics and grain yield in winter wheat. Photosynthetica 42:439-446.

Jin, S.H., J.Q. Huang, X.Q. Li, B.S. Zheng, J.S. Wu, Z.J. Wang, et al. 2011. Effects of potassium supply on limitations of photosynthesis by mesophyll diffusion conductance in Carya cathayensis. Tree Physiology 31:1142-1151.

Johnstone, P.R., T.K. Hartz, M.D. Cahn, and M.R. Johnstone. 2005. Lettuce response to phosphorus fertilization in high phosphorus soils. HortScience 40:1499-1503.

Kalaji, H.M., Govindjee, K. Bosa, J. Koscielniak, and K. ZukGolaszewska. 2011. Effects of salt stress on photosystem II efficiency and $\mathrm{CO}_{2}$ assimilation of two Syrian barley landraces. Environmental and Experimental Botany 73:64-72.

Katan, M. 2009. Nitrate in foods: Harmful or healthy? American Journal of Clinical Nutrition 90:11-12.

Kim, H., G. Goins, R.M. Wheeler, and J.C. Sager. 2004 . Green-light supplementation for enhanced lettuce growth under red- and bluelight-emitting diodes. HortScience 39:1617-1622.

Lambers, H., F.S. Chapin III, and T.L. Pons. 2008. Plant physiological ecology. $2^{\text {nd }}$ ed. Springer Science, New York, USA.

Lauchli, A., and S.R. Grattan. 2007. Plant growth and development under salinity stress. p. 1-32. In Jenks, M., P. Hasegawa, and S.M. Jain (eds.) Advances in molecular breeding toward drought and salt tolerant crops. Springer, New York, USA.

Maathuis, F.J.M. 2009. Physiological functions of mineral macronutrients. Current Opinion in Plant Biology 12:250-258.

Marshall, B., and P.V. Biscoe. 1980. A model for C3 leaves describing the dependence of net photosynthesis on Irradiance. Journal of Experimental Botany 31:29-39.

Munns, R., and M. Tester. 2008. Mechanisms of salinity tolerance. Annual Review of Plant Biology 59:651-681.
Oki, L.R., and J.H. Lieth. 2004. Effect of changes in substrate salinity on the elongation of Rosa hybrida L. 'Kardinal' stems. Scientia Horticulturae 101:103-119.

Pavlou, G.C., C.D. Ehaliotis, and V.A. Kavvadias. 2007. Effect of organic and inorganic fertilizers applied during successive crop seasons on growth and nitrate accumulation in lettuce. Scientia Horticulturae 111:319-325.

Poorter, H., K.J. Niklas, P.B. Reich, J. Oleksyn, P. Poot, and L. Mommer. 2012. Biomass allocation to leaves, stems and roots: meta-analyses of interspecific variation and environmental control. New Phytologist 193:30-50.

Postma, J.A., and J.P. Lynch. 2011. Root cortical aerenchyma enhances the growth of maize on soils with suboptimal availability of nitrogen, phosphorus, and potassium. Plant Physiology 156:1190-1201.

Rivas-Ubach, A., J. Sardans, M. Perez-Trujillo, M. Estiarte, and J. Peñuelas. 2012. Strong relationship between elemental stoichiometry and metabolome in plants. Proceedings of the National Academy of Sciences of the United States of America 109:4181-4186.

Rubio, G., J. Zhu, and J.P. Lynch. 2003. A critical test of the two prevailing theories of plant response to nutrient availability. American Journal of Botany 90:143-152.

Santamaria, P. 2006. Nitrate in vegetables: toxicity, content, intake and EC regulation. Journal of the Science of Food and Agriculture 86:10-17.

Silber, A., G. Xu, I. Levkovitch, S. Soriano, A. Bilu, and R. Wallach. 2003. High fertigation frequency: the effects on uptake of nutrients, water and plant growth. Plant and Soil 253:467-477.

Svistoonoff, S., A. Creff, M. Reymond, C. Sigoillot-Claude, L. Ricaud, A. Blanchet, et al. 2007. Root tip contact with lowphosphate media reprograms plant root architecture. Nature Genetics 39:792-796.

Unlukara, A., B. Cemek, S. Karaman, and S. Ersahin. 2008 Response of lettuce (Lactuca sativa var. crispa) to salinity of irrigation water. New Zealand Journal of Crop and Horticultural Science 36:265-273.

Vitousek, P.M., R. Naylor, T. Crews, M.B. David, L.E. Drinkwater, E. Holland, et al. 2009. Nutrient imbalances in agricultural development. Science 324:1519-1520.

Zhang, L., and D. Xing. 2008. Rapid determination of the damage to photosynthesis caused by salt and osmotic stresses using delayed fluorescence of chloroplasts. Photochemical and Photobiological Science 7:352-360. 